\title{
THE CHALLENGES OF IMPLEMENTING RUSSIA'S SECURITY STRATEGY IN THE ARAB GULF COUNTRIES AFTER THE ARAB SPRING
}

\author{
Mazin Said Almaqbali \\ Peoples' Friendship University of Russia (RUDN University) \\ Miklukho-Maklaya str., 6, Moscow, Russia, 117198
}

\begin{abstract}
The paper deals with the Russia's policy in the Middle East. Considered Russia's security strategy and interests in the Arab Gulf. Illuminated the influence of the Arab Spring events on the relationship of Russia and Gulf states.
\end{abstract}

Key words: Russian foreign policy, security strategy, Arab Spring, GCC

\section{INTRODUCTION}

By 2010, Russia had succeeded in strengthening its influence in the Middle East, having established good relations with each government and with most of its resistance movements. However, after the events of the Arab Spring in 2011, Russia lost some of this influence in the region briefly during the early Arab Spring, which Russia describes as a series of coups against governments started in some countries of North Africa in 2011 by the US private services, where Russia saw the hands of the West, especially the United States of America in these coups, which threatens the interests of Russia in the region, including security interests, and then Russia sought to, for example, Russian President Putin arrived to the leader of the Muslim Brotherhood in Egypt, Mohamed Morsi. Although the Russian Supreme Court had designated this group as a terrorist organization in 2003, Putin has revealed that although he prefers to work with the secularists in Egypt, he will work with the Islamists to secure Russia's influence in the region, even if this group, in the view of the Kremlin, encourages terrorism and supports instability in Russia [1. P. 2-3].

The Russian interest in the Middle East, including the Arab Gulf states, has shown that Russia has cooperated with a terrorist organization - in the eyes of the Russian Kremlin - in order to strengthen its influence in the region, indicating that Russia is ready to do anything for the sake of to build its influence in the region because of the strategic importance of this region to Russia, and this paper comes to try to identify the range of challenges facing Russia in the implementation of its security strategy in the region, specifically in the Arabian Gulf, after the events of the Arab Spring. To illustrate this, the study board was divided into the following axes.

\section{FIRST: RUSSIA'S SECURITY STRATEGY}

In its security strategy for the period 2010 - 2012, Russia has made significant changes, most notably: reconsidering its view of the West. It no longer views the West as a security challenge but as a partner to face global challenges. Russia's security strategy 
also laid out a new framework for Russian security policy based on national strategic priorities in the areas of defense and security of the state and society and sustainable development, where the new security strategy of Russia is centered on the need to improve the quality of life of Russian citizens, and takes a less hostile attitude towards the United States and NATO, and despite this its new strategic security of Russia, but it is still considered to Western countries, countries compete to achieve their interests, including security in all parts of the world [3. P. 1-2].

As for the Middle East region, including the Gulf states, the most prominent political analysts stressed that this region is less important than Europe and Asia in Russia's security strategy, where Russia sees relatively limited opportunities in the Middle East to protect or strengthen its vital interests. This region was driven by international prestige, trade and regional stability, not driven by a political vision or a special strategy for Russia in the Middle East, based on its belief that it was a global force that was pushing it to play certain roles in this region only [6. P. 2-3].

Although the Middle East occupies the third place in the Russian priority after Europe and Asia, the Middle East is of strategic importance to Russia, which stems from a number of reasons, including: physical-geographical proximity between Russia and the Middle East, where Iraq is about $600 \mathrm{~km}$ from the Chechen capital «Grozny». There is no ideological or physical wall that separates the Russian Muslims - who make up about seven of the population of Russia — with their brothers in the Middle East, and any religious or political unrest in the region will certainly be affected by Russia. The Middle East is rich with energy resources, not to mention that about $20 \%$ of the Jews in Israel are of Russian origin and speak Russian [7. P. 3-4].

\section{SECOND: RUSSIAN INTERESTS IN THE ARAB GULF AFTER THE ARAB SPRING}

The Gulf states are a strong strategic partner for energy with Russia and a competitor at the same time, as the Gulf states have a large strategic stocks of oil and gas, and the Gulf market is an important market for the consumption of Russian high-tech products [7. P. 5].

After the violent and rapid changes brought about by the Arab Spring in 2011 to Asian Arab countries such as Yemen and Syria, Moscow's fear that these changes could lead to profound changes that negatively affect their interests, while Russia did not consider the events of the Arab Spring as a comprehensive event and Russia evaluated the events of the Arab Spring in each country on the basis of how this affects their interests. In other words, what matters to Russia is to preserve its interests in the region by making every event in a country separate from the events in the region. To ensure that their interests remain with other countries such as the Gulf states where Russia is interested in preserving its interests with the Gulf states, although Russia's interests with these countries are of a short-term dimension, for the most part, Russia is not in depth in the Gulf region, unlike the United States of America with long-term strategic interests [7. P. 5].

Russia has also paid great attention to the Syrian revolution, which began in 2011 more than any revolution of the Arab Spring revolutions. This concern was at the expense 
of its interests with the GCC countries, especially Saudi Arabia. Since the outbreak of the Syrian civil war, relations between Russia and the GCC have deteriorated sharply because of the differences between the two parties on the future of Syrian President «Bashar al-Assad», has supported Russia, «Assad» strongly claiming that his regime is a bulwark against Islamic extremism, while supported by the GCC countries led by Saudi Arabia to overthrow «Assad», because the demise will reduce the regional impact to Iran, in addition to war the Russian oil is Saudi Arabia because of the Russian position on Assad, which has led many analysts to say that Russia's relations with the GCC countries are in a historical turn. Nevertheless, Russia has sought to strengthen its economic relations with the rest of the GCC countries such as Qatar, Oman, Saudi Arabia it has failed to develop strategic security alliances with the rest of the GCC, prompting Saudi policy makers to consider Russia a marginal player in the Gulf, while before the Syrian crisis, Saudi Arabia considered Russia's policy in the Gulf to be completely mercenary, as many of the decision makers Saudi and many Saudi policymakers now believe that they will be able to obtain Russia compliance with Riyadh's policy because of Riyadh's preferences for Russia , simply by preventing Iran to be business partner and purchase of Russian weapons [5].

\section{THIRD: CHALLENGES FACING RUSSIA IN THE REGION}

As we have seen previously, the Russian security strategy has been affected by many changes, including turning the case of hostility with Western countries to a competitive situation, and the Gulf region as part of the Middle East, a region of low strategic importance compared to Europe and Asia, with the Arab Gulf States are nonlong-term interests. In addition, Russia has given the Syrian revolution great importance at the expense of its relationship with the Gulf states. Nevertheless, it has become clear to us that the Middle East in general and the Arabian Gulf in particular are important for Russia. So Russia is keen to preserve its interests in one way or another, on other hand we find that there is no Russian security strategy especially towards the Persian Gulf, but there is only a set of Russian interests with the Gulf countries, which basically economic interests can change from time to time, and that the world sense is what drives Russia as a superpower to intervene in the region's issues, not from its own strategy. Although Russia is making concerted efforts to become a major supplier of arms to the countries of the region and the Gulf states [6. P. 9]. Russia faces a number of challenges in achieving its objectives in the Gulf region:

1) US-GCC Relations. Given the size of its economy and its political and military capabilities, the United States will remain the most prominent player in the Middle East. Its strategic relations will remain stronger than any other country in the region, especially the Gulf states and Israel. The United States has maintained its strong relationship with the Gulf states in addition to maintaining Israel's security. The events of the Arab Spring have not affected this great and strong position of the United States of America with the Gulf states, a major challenge for every country seeking to strengthen its influence in this region are China and Russia [2].

2) Russian-Israeli Relations. Although Russia has adopted the Israeli position in the Israeli-Palestinian conflict because of many Russian factors and interests with Israel, 
Russia is not trying to lose its interests with the Arabs, especially with the Gulf states. Russia appears to be the neutral mediator between the Arabs and Israel, which is a major challenge to strengthen Russian relations with the Gulf states, since the Russian position is exposed to the Arabs that Russia is leaning towards Israel [7. P. 9].

3) Russia's interest in the Syrian issue. Russia played the role of a strong ally of the Syrian regime led by President Bashar al-Assad against the popular revolution that sought to overthrow him. Russia has done everything to stabilize the Assad regime for many reasons. The Assad regime is the most efficient to prevent radical Islamist movements from growing, which, as we have seen, has led to the deterioration of Russia's relations with the Gulf Cooperation Council (GCC) states that sought to topple Bashar Assad's regime [4. P. 32].

In addition to all these challenges, if Russia wants to identify and pursue a comprehensive long-term security strategy in the Middle East and the Arabian Gulf, Russia will not be able to do so, because Russia lacks the economic and military potential to achieve this comprehensive security strategy. Russia lacks the potential for soft power compared with the West.

\section{CONCLUSION}

— There is no Russian security strategy for the Middle East, including the Gulf states.

- Russia is associated with economic interests with GCC countries, and these interests are the main driver of Russia in its relationship with the Gulf states.

- The events of the Arab Spring have negatively affected Russia's relations with the GCC countries, where relations have deteriorated significantly.

- The Kingdom of Saudi Arabia is the most tense Gulf Cooperation Council with Russia, after the Arab Spring, despite the existence of relations and significant economic benefits to Russia with Saudi Arabia.

- The main challenges facing the Russian economic policy in the Arab Gulf region, after the Arab Spring, are: the American, the Israeli, and the Syrian specific.

- Russia does not have the means to draw up and implement a comprehensive long-term security strategy for GCC countries in particular and the Middle East as a whole.

\section{REFERENCES}

1. Borshchevskaya A. Russia's Strategic Objectives in the Middle East and North Africa. USA, The Washington Institute for Near East Policy; 2017: 2-3.

2. Keiswetter A. The Arab Spring: Implications for US Policy and Interests. Middle East Institute. Available from: http://www.mei.edu/content/arab-spring-implications-us-policy-and-interests.

3. Morales J. Russia's New National Security Strategy: Towards a Medvedev Doctrine? Real Institute Elcano; 2009: 1-2.

4. Notte H. Russia's Role in the Syrian War-Domestic Drivers and Regional Implications. Maison Du Futur-Policy Papers; 2017.

5. Ramani S. How Russia is Courting the Gulf. The National Interest. Available from: $\mathrm{http} / / /$ nationalinterest.org/feature/how-russia-courting-the-gulf.

6. Sladden, J. et al. Russian Strategy in the Middle East. RAND Corporation; 2017: 2-3.

7. Trenin D. Russia's Policy in the Middle East: Prospects for Consensus and Conflict with the United States. The Century Foundation; 2010: 3-4. 
DOI: 10.22363/2313-1438-2018-20-1-31-35

\title{
ПРОБЛЕМЫ РЕАЛИЗАЦИИ СТРАТЕГИИ БЕЗОПАСНОСТИ РОССИИ \\ В СТРАНАХ ПЕРСИДСКОГО ЗАЛИВА ПОСЛЕ «АРАБСКОЙ ВЕСНЫ»
}

\author{
Аль-Макбали Мазин Саид Мусабах \\ Российский университет дружбы народов \\ ул. Миклухо-Маклая, 6, Москва, Россия, 117198
}

В статье рассматривается политика России на Ближнем Востоке. Автором рассмотрена стратегия безопасности России и ее интересы в Персидском заливе. Освещено влияние политических событий «Арабской весны» на отношения России и стран Персидского залива.

Ключевые слова: Российская внешняя политика, стратегия безопасности, «Арабская весна», ССАГПЗ

\section{Информация об авторе:}

Аль-Макбали Мазин Саид Мусабах — аспирант кафедры сравнительной политологии Российского университета дружбы народов (Оман) (e-mail: mazinalmaqbali@gmail.com)

Information about the author:

Mazin Said Almaqbali - postgraduate student of the Department of Comparative Politics of Peoples' Friendship University of Russia (RUDN University) (Oman) (e-mail: mazinalmaqbali@gmail.com)

Статья поступила в редакцию 10.08.2017. 